\title{
A Free Active Learning Approach to an Information Technology Seminar Course
}

\author{
Moshe Pelleh \\ School of Management, Peres Academic Center, Rehovot
}

\author{
mpelleh@yahoo.com
}

\begin{abstract}
Academic institutions are at a turning point. The classic face-to-face approach to teaching might not be accepted by the current generation of students who need to develop skills of creativity and self-learning to compete and survive in the fast changing modern world. For several years the author has been trying to meet these needs. This paper describes a course entitled 'Seminar in Information Technology' and the students' feedback on the course. Courses in Information Technology (IT) are essential in Business Administration (BA) education. The course provides the students with an excellent opportunity to experience the interplay between ideas and their implementation. Specifically, we tried a self-learning approach, which can be considered as a derivative of project-based-learning (PBL) instructional design, adapted for an IT course in a BA faculty. This paper presents our experience of an IT course based on continuing evolving independent work. The findings of a preliminary assessment indicate a highly positive attitude on the part of the students towards this approach as well as towards the qualitative evaluation method that was used to assess their achievements.
\end{abstract}

Keywords: Information technology, business administration, project-based learning, activelearning, system-level perspective, professional practice.

\section{Introduction}

In the modern world, practical information technology integrates business administration with computerized applications. The dynamics of the field of computing along with strengthening ties between IT and business administration require suitable manpower to be trained.

The Peres Academic Center (PAC) meets this need and offers a suitable academic track in business administration. PAC is an institution of higher learning that specializes in the scientific, professional, social and cultural aspects of advanced business administration. The institute awards degrees including a Bachelor in Business Administration (BBA). Since the development of mod-

Material published as part of this publication, either on-line or in print, is copyrighted by the Informing Science Institute. Permission to make digital or paper copy of part or all of these works for personal or classroom use is granted without fee provided that the copies are not made or distributed for profit or commercial advantage AND that copies 1) bear this notice in full and 2) give the full citation on the first page. It is permissible to abstract these works so long as credit is given. To copy in all other cases or to republish or to post on a server or to redistribute to lists requires specific permission and payment of a fee. Contact Publisher@InformingScience.org to request redistribution permission. ern organizations requires the training of highly skilled and responsible personnel, PAC's primary educational vision is:

To educate top class students, not only to serve Israel, but to do so with one eye on their career, the other on social responsibility. Through carefully crafted programs and a groundbreaking curriculum, we are creating a new type of graduate - one who seeks professional- 
ism, but not at the expense of a sustainable community and environment.

Pioneer in new learning techniques, protect of human values, and a place where academics and students meet to explore ideas and share their common belief in moral objectives. PAC graduates - the leaders of tomorrow - learn not to exploit those around them, but to profit from responsibility. The Center focuses on Corporate Social Responsibility and Community Involvement, and on bringing responsible performance to business. It emphasizes ethics in commerce and industry, adding dimensions of care, attention and compassion.

Not satisfied with traditional face-to-face lecturing, PAC faculty keep close tabs on students' performance - guiding, encouraging, and assisting whenever requested. The Personal Professor changes the emphasis from dry academic teaching to personal mentoring.

The focus shifts from the course to the student - a revolutionary technique pioneered by the forward-thinking Behavioral Sciences faculty. A student is no longer just another face in the front row of statistics - but a human being, harboring aspirations, doubts, ambition, responsibilities, and a genuine will for self-improvement.

\section{Project-Based Learning (PBL)}

The academic Computer Science (CS) community believes that the role of projects in the curriculum is of great importance. Final projects are recognized as valuable for enhancing student knowledge and especially for acquiring a system-level approach. Since the nature of work within most modern organizations is moving from individual assignments to team and project-based activities, it is important to integrate projects into the learning process to simulate real world professional situations. However, the integration of such projects should be carefully designed, not merely as "post-course" projects (ACM/IEEE Joint Task Force on Computing Curricula, 2001). In recent years, the potential of project-based learning has been noted (Fincher \& Petre, 1998; Matsuura, 2006). Project-based learning (PBL) is a constructivist pedagogy that intends to bring about deep learning by allowing learners to use an inquiry based approach to engage with complex issues that require students to investigate in order to understand ("Project-based Learning", n.d.). Constructivism describes how learning should happen, regardless of whether learners are using their experiences to understand a lecture or attempting to design an artifact. The theory of constructivism suggests that in both cases, learners construct knowledge (Ben-Ari, 2001; von Glasersfeld, 1989). Constructivism is often associated with pedagogic approaches that promote learning by doing, such as: active learning (Bonwell \& Eison, 1991) and cooperative learning (Bossert, 1988). Project-based learning shifts the emphasis away from a traditional teachercentered approach to student-centered teaching and active and cooperative learning. Project-based learning is very different from traditional learning in which the student deals mainly with short exercises and well-defined "local" problem solving tasks. Project work on the other hand requires the student to develop an entire system which is assembled from "small pieces". Actually, the PBL approach emphasizes on long-term, student-centered learning activities and on students' own construction of artifacts to represent what is being learned. In a project-based framework students must collaborate with peers, organize their own work, and manage their own time.

Based on the above considerations, the PBL approach enables students to construct knowledge and to enhance their cognitive and reflective skills; it encourages students to become creative and independent learners, and it enables them to gain real experience as project developers (Fincher, Petre, \& Clark, 2001; Holcombe, Stratton, Fincher, \& Griffiths, 1998). The approach can be very suitable to prepare undergraduates for their professional life, when cooperative working will form a major part of their work duties (Wegner, 1998). The Critical Thinking Test proves that students learning according to the PBL method acquire much better reasoning capability than students learning according to the traditional method (Shepherd, 1998). 


\section{Active Learning}

Active learning refers to several models of instruction that focus the responsibility of learning on learners. Bonwell and Eison (1991) popularized this approach to instruction in a report to the Association for the Study of Higher Education (ASHE). In this report they discuss a variety of methodologies for promoting active learning. They cite literature which indicates that to learn, students must do more than just listen: They must read, write, discuss, or be engaged in solving problems. In particular, students must engage in such higher-order thinking tasks as analysis, synthesis, and evaluation.

A student debate is an active way for students to learn because they allow students the chance to take a position and gather information to support their view and explain it to others. These debates not only give the student a chance to participate in a fun activity but it also lets them gain some experience with giving a verbal presentation (Active Learning, n.d.; McKinney, 2010).

Significant learning is achieved if the student feels the theme is connected to his aims (Rogers, 1969), so it is best for the student to choose a theme according to his interests.

Producing a project or a seminar involves synthesis, which is a higher-grade thinking process than analysis.

PBL can be seen as a tool in our active learning approach.

\section{The Information Technology Seminar Course}

This course uses an active learning method where each team prepares a seminar work during the semester and then presents it to the class. The work is built in stages. In each lesson the missions prepared for the current lesson are checked and the missions for the next lesson are defined and explained, until the seminars are ready and then each team in turn will present its seminar. In the first lesson the lecturer explains the active learning method and presents a few seminar works as examples. The next few lessons are team guidance and the last lessons are presentations and debates. The course is intended to achieve the following goals:

- Learning a professional matter in information technology / data base / internet / data communication / operating system or its application in business.

- Analyze and research the selected theme.

- Write a seminar work (synthesis) and present it to the class members for debate.

The course differs from other courses as follows:

- The whole course is based on independent work, hence it is active learning.

- Each team selects its own theme, hence it is free active learning.

- The final grade is based solely on the seminar work.

Some examples of selected seminar themes:

- An artificial intelligence system for an organization.

- Virtual servers.

- Safety and privacy in cloud computing.

- The influence of IT on financial institutions.

- Client trust in electronic commerce.

- Biometric identification.

- Search engines.

- Advertizing with the Internet.

- Service improvement in the municipality using IT systems. 


\section{Evaluation of a Seminar}

The criteria for evaluating a project and for assigning grades are based on the following factors:

1. Quantitative: format, organization, chapters, and paragraphs.

2. Qualitative: how many topics are implemented in the seminar, logical flow and clear descriptions.

3. Depth: how the topics were implemented, usage of mathematical or statistical formulas, usage of questionnaires, usage of recent scientific papers or company specifications, etc.

\section{Student Feedback}

In order to get the students' feedback on the course, an anonymous questionnaire was distributed in the last week of the semester. A total of 43 students responded. 27 students out of this total of 43 students also answered the open questions. The questions and results are presented in Table 1 below.

\section{Table 1: The Results of Students' Feedback Forms $(\mathbf{N}=43)$ \\ Scale: yes $/$ match $/$ effective $=1$, maybe $=0.5$, no $=0$ \\ Score: minimum $=\mathbf{0}$, maximum $=\mathbf{1 0 0}$}

\begin{tabular}{|c|c|c|c|c|c|}
\hline & Question & $\begin{array}{l}\text { Yes/ } \\
\text { match/eff } \\
\text { ective } \%\end{array}$ & Maybe \% & No $\%$ & Score $\%$ \\
\hline 1 & $\begin{array}{l}\text { How effective were the given instructions and } \\
\text { the guidelines before and during your work on } \\
\text { the project? }\end{array}$ & 95 & 2 & 2 & 96 \\
\hline 2 & $\begin{array}{l}\text { Did the seminar match the material studied in the } \\
\text { track? }\end{array}$ & 93 & 2 & 5 & 94 \\
\hline 3 & $\begin{array}{l}\text { Did the seminar help you understand and plan } \\
\text { the theme better? }\end{array}$ & 95 & 0 & 5 & 95 \\
\hline 4 & Is the workload of the course high? & 60 & 26 & 14 & 73 \\
\hline 5 & Do you prefer a theme to your choice? & 91 & 7 & 2 & 95 \\
\hline 6 & $\begin{array}{l}\text { Do you prefer a course which is solely independ- } \\
\text { ent work? }\end{array}$ & 81 & 7 & 12 & 85 \\
\hline 7 & Did you enjoy the course? & 88 & 5 & 7 & 91 \\
\hline 8 & Was the course useful for you? & 77 & 14 & 9 & 84 \\
\hline 9 & $\begin{array}{l}\text { Would you recommend to your friends to take } \\
\text { this course? }\end{array}$ & 86 & 7 & 7 & 90 \\
\hline 10 & $\begin{array}{l}\text { What are your com- } \\
\text { ments? }\end{array}$ & & & & \\
\hline
\end{tabular}

Some selected comments (and author's responses):

- Enriching lessons should be added. (Response: having passed courses in information technology, ERP, data communication and operating systems, we are now challenging your capability to cope with new themes.)

- Weak framework - not suitable to everybody. (Response: self-discipline is a precondition for becoming a manager or a team leader.)

- Encouraging thinking and developing. (many others similar) 
- Learning a lot of interesting matters.

- Attached to a time table that does not allow me to delay the missions to the end of the semester, on the other hand I can control my free time.

- Developing independent thinking and cognitive capabilities.

- Encouraging open and independent work. (many others similar)

- Excellent, wonderful, effective, flexible weekly hours. (many others similar)

\section{Late Post Reflection}

A few students sent a letter to the CEO of PAC with copies to the president of PAC, the chairman of PAC, the head of academic staff and the head of students' administration, in which they expressed their appreciation of this unique method of learning and wished for other courses like this.

\section{Comparison to Our Previous Work}

It is interesting to compare the feedback forms with those of previous research (Pelleh, Haberman, Rosenthal, \& English, 2008). This previous research was conducted in the context of an operating systems course, in a Computer Science faculty, using the PBL method to make a project in addition to the face-to-face lectures. The comparative results are shown in Table 2. From answers to question 8 we can see that the PBL (lectures + project) is a very effective method. On the other hand, students prefer the free active method (solely independent work) as seen from the answers to the question 6. I presume that creating an operating system as a project is a heavier task than any theme the students will choose, especially when the work is accompanied with whole course lectures.

Table 2: Comparative Results of Students' Feedback Forms

\begin{tabular}{|c|c|c|c|}
\hline & Question & $\begin{array}{l}\text { Previous } \\
\text { score \% }\end{array}$ & $\begin{array}{l}\text { Recent } \\
\text { Score \% }\end{array}$ \\
\hline 1 & $\begin{array}{l}\text { How effective were the given instructions and the } \\
\text { guidelines before and during your work on the project? }\end{array}$ & 93 & 96 \\
\hline 2 & $\begin{array}{l}\text { Did the seminar/project match the material studied in } \\
\text { the track/class? }\end{array}$ & 97 & 94 \\
\hline 3 & $\begin{array}{l}\text { Did the seminar/project help you understand and plan } \\
\text { the theme/course material better? }\end{array}$ & 97 & 95 \\
\hline 4 & Is the workload of the course high? & 69 & 73 \\
\hline 5 & Not the same question. & $\mathrm{N} / \mathrm{A}$ & $\mathbf{N} / \mathbf{A}$ \\
\hline 6 & $\begin{array}{l}\text { Do you prefer a course which is solely independent } \\
\text { work? }\end{array}$ & 63 & 85 \\
\hline 7 & Did you enjoy the course? & 93 & 91 \\
\hline 8 & Was the course useful for you? & 92 & 84 \\
\hline 9 & $\begin{array}{l}\text { Would you recommend to your friends to take this } \\
\text { course? }\end{array}$ & 94 & 90 \\
\hline
\end{tabular}




\section{Conclusions}

In this paper we have shown how an active learning framework has been applied to the teaching of an information technology course at the undergraduate level. The course provided the students with an excellent opportunity to experience the interplay between theory and practice. The active learning educational approach could also be applied in other courses that combine theoretical and practical aspects. We have presented how the concept of 'active learning' can be embedded in a pedagogical framework, combining traditional and modern didactical methods. The seminar works were designed to involve gradually increasing levels of difficulty; as a result, the students approached the complexity of the system incrementally. Using this approach we enabled students to solve practical problems in a realistic environment that simulates 'real world' organizational scenarios. The findings of our preliminary assessment indicated a highly positive attitude on the part of the students towards the teaching and learning approach employed in the course as well as towards the qualitative evaluation method that was used to assess their achievements. The overall course assessment demonstrates the pedagogical value and effectiveness of the active learning model as a means of improving students' personal, collaborative and communication skills. The course resulted in students changing many of their attitudes towards learning and assessment and they started to adopt a more professional way of thinking.

Although most students are full time employed, the quality of their work was high, they participated enthusiastically in the presentations and the subsequent debates, their feedback were positive particularly with regard to workload and individual control of free time. I conclude that the ability to control their time to meet fixed deadlines improved their results.

In an era with frequent advances in knowledge and effectively unlimited storage it is essential to know how to find relevant information, how to learn it, and how to use it. The exact themes covered in this course are relatively unimportant. The important thing is to have learnt how to learn a new topic and how to apply the knowledge in a practical way.

\section{References}

ACM/IEEE Joint Task Force on Computing Curricula. (2001). Final Report, December 2001.

Active Learning. (n.d.). In Wikipedia. Retrieved September 2013 from http://en.wikipedia.org/wiki/Active_learning

Ben-Ari, M. (2001). Constructivism in computer science education. Journal of Computers in Mathematics and Science Teaching, 20(1), 45-73.

Bonwell, C., \& Eison, J. (1991). Active learning: Creating excitement in the classroom. AEHE-ERIC Higher Education Report No.1. Washington, DC: Jossey-Bass.

Bossert, S. T. (1988). Cooperative activities in the classroom. Review of Educational Research, 15, 225250.

Fincher, S., \& Petre, M. (1998). Project-based learning practices in computer science education. In proceedings of: IEEE Frontiers in Education Conference, Tempe, Arizona, USA, November, 1185-1191.

Fincher, S., Petre, M., \& Clark, M. (Eds.). (2001) Computer science project work principles and pragmatics. London: Springer-Verlag.

Holcombe, M., Stratton, A, Fincher, S., \& Griffiths, G. (Eds.). (1998). Projects in the computing curriculum. Proceedings of the Project 98 Workshop. London: Springer-Verlag.

Matsuura, S. (2006). An evaluation method of project based learning on software development experiment. Proceedings of SIGCSE'06, Houston, Texas, USA, March, 163-167.

McKinney, K. (2010). Active learning. Illinois University. Center for Teaching, Learning \& Technology. 
Pelleh, Haberman, Rosenthal, \& English (2008). Linking theory, practice and system-level perception. Issues in Informing Science and Information Technology, 5, 395-408. Retrieved from http://proceedings.informingscience.org/InSITE2008/IISITv5p395-408Pelleh442.pdf

Project-based Learning. (n.d.). In Wikipedia. Retrieved September 2013 from http://en.wikipedia.org/wiki/Project-based_learning

Rogers, C. (1969). Freedom to learn: A view of what education might become (1st ed.). Columbus, Ohio: Charles Merill.

Shepherd, H. G. (1998). The probe method: A project - based learning model 's effect on critical thinking skills. Dissertation Abstracts International, Section A, 59(3A), 779.

von Glasersfeld, E. (1989). Cognition, construction of knowledge, and teaching. Synthese, 80, 121-140.

Wegner, E. (1998), Communities of practice: Learning, meaning and identity. UK: Cambridge University Press.

\section{Biography}

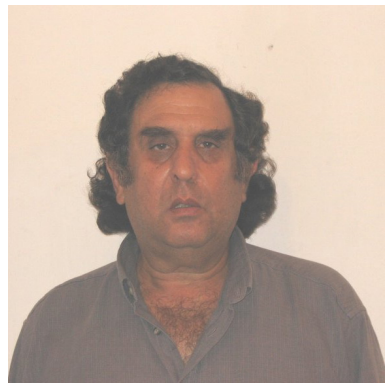

After completing his doctoral studies at the University of Pisa, Moshe Pelleh developed several advanced projects in the communication and aerospace industries involving real time embedded systems. In recent years Dr. Pelleh has been a senior lecturer in Holon Institute of Technology, teaching courses in Network Communications, Operating Systems, Real Time Systems and Embedded Systems, and as the founder and head of the Real Time Embedded Systems Laboratory. His research is centered in the field of Real Time Embedded Systems. He is now based the Peres Academic Center in the school of management as a lecturer in computer related courses 